\title{
The Use of Natural Additive Substances on Sasirangan Dying as a Medium of the Local Wisdom Characters
}

\author{
Muhammad Kusasi \\ Chemical Education \\ Faculty of Teacher Training and Education \\ Universitas Lambung Mangkurat \\ Banjarmasin, Indonesia \\ Muhammadkusasi64@gmail.com
}

\begin{abstract}
Sasirangan is a traditional cloth of Banjar tribe of South Kalimantan. Sasirangan fabric is a type of fabric that is given a picture with the shades of the border-like stripes that extend from the bottom to the top (vertical). Staining of Sasirangan can be used from natural additive chemicals. There are six main colors of Sasirangan made from natural dyes additive chemicals found in South Kalimantan, namely: 1. Yellow from turmeric, 2. Red from gambier, noni fruit, red lombok, 3. Green, from pudak leaves or ginger, 4. Black from kabuau or uar, 5. Purple from seeds of gandaria (Ramania), and 6. Brown from uar or rambutan peel. In fact, Sasirangan can be used as a medium in instilling characters on learning in school. The characters that can be constructed through learning using natural substance chemicals substance on Sasirangan dying are: confidence, cultural, and economic value.
\end{abstract}

Keywords-character value; dying; natural additive chemical; Sasirangan fabric

\section{INTRODUCTION}

Indonesia has unparalleled diversity and uniqueness. It is contained in the works that have been recognized by the wider community. Many of them have been recognized internationally as a cultural heritage. One of them is Batik as a cultural work that contained an artistic value. Nowadays, Batik is very closely to the tribes' culture. In Indonesia, Batik does not only come from Java but also from Borneo with its own uniqueness, beauty, and characteristics. One of them is Sasirangan from Banjarmasin, South Borneo. On the contrary with the motives, Javanese Batik is divided based on the social classes of the people who wear it. Since the ancient time, Sasirangan is used by various classes and social classes of Banjarmasin society.

Etymologically, Sasirangan term is not a noun as implied by the above understanding, but is a verb. "Sa" means one and "sirang" means baste. It means "Sasirangan" is a thing made into one baste. It is identical with the cloth that is given the image with the shades of the bold-shaped stripes that extend from the bottom up (vertical). Nevertheless, the term of Sasirangan has been agreed socially (arbitrary) to fabricshaped objects.
The word Sasirangan itself is derived from the word "menyirang" which means baste associated with the way of making this Batik. Sasirangan is a typical cloth of Banjarmasin in South Borneo which is made with stinging technique, tied up thread, rubber band or raffia rope, and then dyed into warm water dyed. Some natural dyes used in dying are the bark of ironwood, ginger, banana peel, and pandan leaves. Historically, Sasirangan among others also published in Banjar Hikayat (the traditional journal of People), from the XII to the XIV century, the first Sasirangan cloth was made during the Negara Dipa kingdom which was then called Langgundi, a yellow woven fabric. At that time, Langgundi cloth was used as fabric to make daily wear of all citizen of Negara Dipa kingdom.

The function at that time is the same as today in which every citizen of the Kingdom is free and entitled to wear them. Until one day, Patih Lambung Mangkurat is meditating on lanting to seek a king for the royal government of the Negara Dipa in accordance with his father's will, Empu Jatmika who did not allow himself and his descendants to become king because they are not from the king's blood. When being imprisoned, Patih Lambung Mangkurat heard a woman's voice asking what he meant and he explained his austerity intent was to seek a king in his kingdom. The woman's voice said that the king being sought by Patih Lambung Mangkurat was herself, but the woman said she would only appear if Patih Lambung Mangkurat fulfilled her request. The woman asked Patih Lambung Mangkurat to make her a magnificent palace built by 40 virgins and a piece of Langgundi fabric woven by 40 virgins, both of which had to be completed within one day. The Patih also agreed and immediately executed it.

After the request was fulfilled, the lady appeared out of the water with her beautifully dressed Langgundi cloth. The woman is called by citizens of the kingdom of the Negara Dipa with the title Princess Junjung Buih, because she emerged from the water rippling/ bubbly. The cloth used is called Calapan cloth which later known as kain Sasirangan. Since that incident, the citizens of Negara Dipa did not dare to use Langgundi/ Sasirangan cloth for fear of against Putri Junjung Buih. This resulted in many Langgundi cloth craftsmen who no longer produced the fabric. However, not all of them stop 
making Sasirangan. There are still some craftsmen who continued making it, but no longer wore it for everyday clothes. Instead, it is used for the treatment of diseases that is magical. From this legend, it turns out that the origin of Sasirangan is not sacred and feels magical. It is profane and does not recognize abstinence or similar things.

Sasirangan on the time of the Kingdom of Banjar was used as a headband or "laung", a belt for men and scarves for women. Even Sasirangan cloth was also used for traditional ceremonies and healing tools for sick people. When it was still called langgundi fabric, it was functioned as a fabric for the fabricant of all layers of society in the Kingdom of Negara Dipa since the golden age of Nan Sarunai Kingdom before being conquered by Empu Jatmika in 1355. This means the function of the Sasirangan (before 1355) refers to a general function as a means to meet the physical needs of all citizens.

Reference [2] argued that ethno-pedagogical learning can be done in several ways. First, it can be from the learning practices and teaching materials that are used as learning media to assist in achieving the goals of learning in the classroom. Teaching materials cannot be separated from teaching and learning activities conducted by teachers in schools. In general, teaching materials used by teachers to simplify and support the effectiveness of teaching and learning in the classroom. Teaching materials are all materials (information, tools, and text) arranged systematically and displayed complete figure of competence that will be mastered by the learners and used in the learning process.

The Sasirangan dyed from natural ingredients made of seeds, fruits, leaves, skins, or tubers of plants growing wild in the forest or are intentionally planted around the dwelling of the Sasirangan in Banjarmasin. It can serve as a medium in an effort to instill the characters on learning in school. The question that we can elaborate and present now is "How is the use of natural chemical substances additives on the color of Sasirangan as a medium of learning in instilling the local wisdom character education in schools?

\section{METHOD}

The method employed in this study is the literature study with a descriptive discussion based on the source of the library obtained. The literature gained is then used as a source to produce the revelation.

\section{DISCUSSION}

\section{A. The Use of Natural Additives Substance on Sasirangan as a Medium of Local Wisdom Character in School}

Sasirangan fabrics are commonly used as custom clothes commonly used in Banjar indigenous events. The word Sasirangan was derived from the word "menyirang" which means baste because it is done in a way to baste then tied with raffia rope and then dyed, until now Sasirangan is still made manually.

According to its history, Sasirangan is a sacred cloth of the XII century heritage when Lambung Mangkurat became the patriarch of Negara Dipa. Originally, Sasirangan is known as a cloth for "batatamba" or healing of sick people who must be specially ordered (pamintaan) so that the making of Sasirangan fabric often follow the will of the buyer. Therefore, Sasirangan is often called as a demand. In addition to the healing of people affected by the disease, this cloth is also a sacred cloth, which is usually used in traditional Banjarese ceremonies.

In the ancient times, Sasirangan was colored in accordance with the purpose of manufacture, namely as a complementary tool in the treatment of a certain type of disease suffered by someone. According to Reference [3], the meaning of the colors is as follows:

- The yellow Sasirangan is a symbolic sign that the wearer is in the process of treating jaundice (Banjar kana wisa);

- The red Sasirangan is a symbolic sign that the wearer is in the process of treating headaches and difficulty sleeping (insomnia);

- The green Sasirangan is a symbolic sign that the wearer is in the process of curing diseases of paralysis (stroke);

- Black Sasirangan is a symbolic sign that the wearer is in the process of treating the fever and skin itching;

- Purple Sasirangan is a symbolic sign that the wearer is in the process of treating stomach pain (diarrhea, dysentery, and cholera);

- The brown Sasirangan is a symbolic sign that the wearer is in the process of treating the illness of stress.

In the ancient times, Sasirangan cloth was colored with dyes made of natural additive chemicals of seeds, fruits, leaves, skins, or tubers of plants that grow wild in the forest or are intentionally planted around the residence of the maker of the Sasirangan fabric itself.

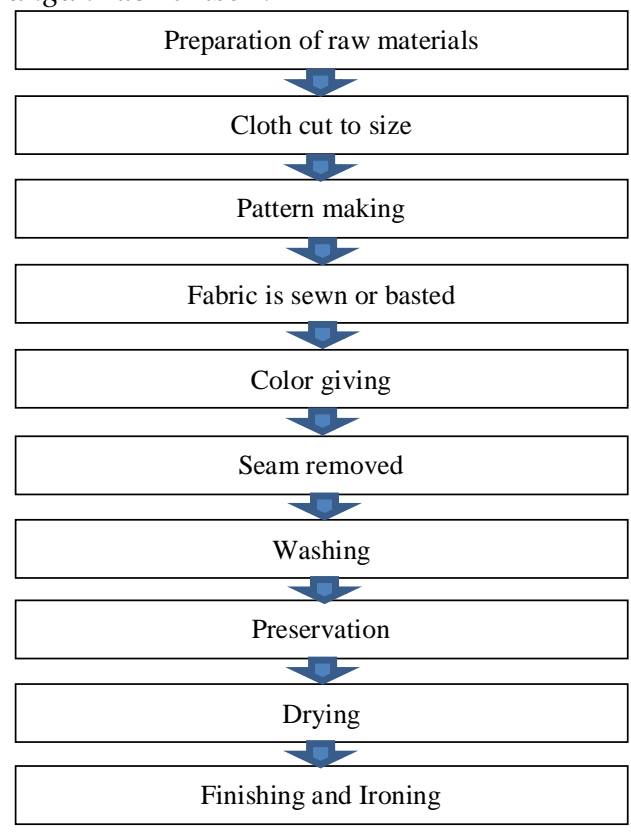

Fig 1. Procedures for making Sasirangan fabrics [1] 
The natural color substance is generally obtained from the extracts of various parts of plants: roots, wood, leaves, seeds, and flowers. Batik craftsmen have been familiar with plants that can color the textile materials, some of which are: tilapia leaves (indofera), bark of soga tingi (ceriops candolleana arn), tegeran wood (cudraina Javanensis), turmeric (сurcuma), tea (morinda citrifelia), jelly soga skin (pelthophorum ferruginum), kesumba (bixa orelana), guava leaf (psidium Guajava) [4].

According to Reference [5], most of the colors can be obtained from plant products. In the plants, there are different pigments of coloring plants depending on their chemical structure. In general, plant pigment classes are chlorophyll, carotenoids, flovonoids, and quinones. Chlorophyll is a genetic term for a number of closely related plant pigments, which produce a green color, such pigments are very abundant in plants. Chlorophyll is sometimes used to color food and drink. Carotenoids are chemically characterized by a long chain of aliphatic pliene composed of isoprene units. The structure of the pigment is very varied and has intensive color properties: yellow, orange, red, and mauve. Examples of caretonoid pigments are bixins obtained from the bixa orellane L (kesumba), crosin obtained from the crocus satifus L (sapran = sapron). Flavonoids composed of compounds whose structure is based on flavo or flavana, the flavonoid subgroup is morin (found in various types of Moraceae tribes). Quinones (Quinomes) include various compounds containing quionic structures, usually yellow to red, the main subgroups are benzokuinon, naftokuinon, and anthraquinone. Examples of naphthokuinone pigments are lowson of lawsonia inermis $\mathrm{L}$ (Henna), the examples of anthraquinone are alizarin, morindin, and purpurin derived from the Rubiaceace tribe.

Other important vegetable dyes are not classified as pigments are the dark blue indigo of the indigofera plant species and from the oxidation of the resulting indoxyl; red crystalline dye called brazilein which is obtained by oxidation of the whitl phenol compounds present in Caesalpinia species: curcumin and turmeric (curcuma longa L) [6]. To make a natural dye solution, it is necessary to take or explore the color pigments in the plant, whether in leaves, stems, fruits, flowers, seeds or roots. The process of exploration/ taking of natural pigment is called the extraction process. This extraction process is done by boiling the material with water solvent. In immersion with natural dye, it is generally required to work on materials to be dyed/ stamped where the mordanting process is done by immersing the material into metal salts such as aluminum, iron, tin or chrome. These mordan substances serve to form a chemical bridge between natural dyes and fibers so that the dyestuff affinity increases with fiber. The dye that has been attached/ seeped on the material can bind strongly and not easily fade the process of fixation (fixer) to lock the color. Commonly, it is used fixer solutions such as alum, lime tohor, Tunjung, java sugar, vinegar, and prusi.

Batik and textile crafts using natural dyes have a high economic selling value because they have artistic, ethnic, and color values to which the impression is exclusive. In an effort to re-establish the use of natural dyes for textiles, the sources of natural dyes are explored. This exploration is intended to know qualitatively the colors produced by various plants. Thus, the results can enrich the source of natural dyes so that the availability of natural dyes always exists and provides more diverse variations in colors. As an early indication, the selected plants waste as a natural dyeing agent is a colored part or if the part of the plant is scrawled onto a white surface leaving a colored scar. Natural dye making can be done using simple technology and equipment.

There are six main colors of Sasirangan cloth made of natural dyes additive substances contained in the area of South Borneo, namely:

- yellow which is produced from turmeric;

- red which is produced from gambier, noni fruit, and red chili;

- green which is produced from pandanus leaves or ginger;

- black which is produced from kabuau or uar;

- purple which is produced from gandaria seeds (Banjar Ramania);

- Chocolate which is produced from uar or rambutan peel.

In order to make darker and durable color, the dye is then mixed with the other spices such as salt, cumin, pepper, nutmeg, clove, lime, lime, alum, vinegar, or terusi. The patterns of Sasirangan cloth are many in number. The common pattern is as follows:

- Iris Pudak (The slice of Pandanus)

- Kambang Raja (The King Flower)

- Bayam Raja (The Spinach King)

- Hulat Kurikit (The Kurikit Caterpillar)

- Ombak Sinapur (The Wave of Sinapur)

- Bintang Bahambur (The Stranggled Stars)

- Sari Gading (The Essence of Ivory)

- Kulit Kayu (The Wood Skin)

- Naga Balimbur (Stranggled Dragon)

- Jajumputan (The Pinch)

- Turun Dayang (The Down of Mistress)

- Kambang Tampuk Manggis (The Flower of Magosteen Calyx)

- Daun Jaruju (The Leaf of Jaruju)

- Kangkung Kaombakan (The Waven Kale)

- Sisik Tanggiling (The Pangolin Scales)

- Kambang Tanjung (The Flower of Tanjung)

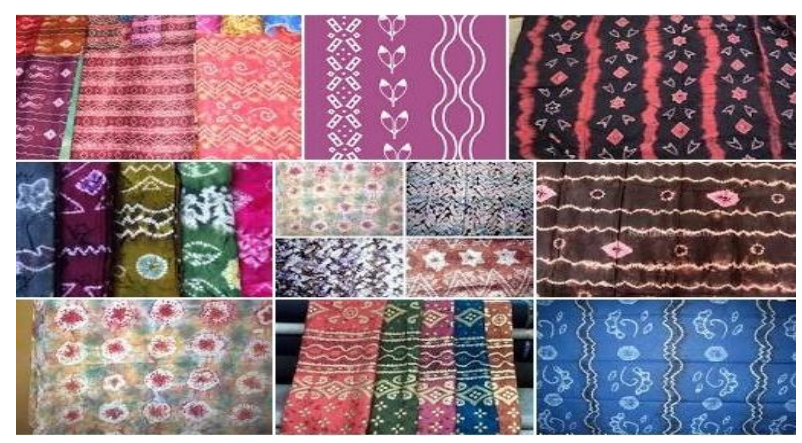

Fig 2. The patterns of Sasirangan [3] 
What is the symbolic meaning implied in the colors of Sasirangan? The main color in the Sasirangan is not just a color with the aim of beauty look of the Sasirangan itself, but there is symbolic meaning behind it which is implied from the colors.

The development of the times has changed the function of Sasirangan in the people of South Borneo. The sacred values contained therein seem to fade away in the current of globalization mode. Globalization makes this cloth not only experienced a deserialization process that changed into everyday fabrics, but also increasingly forgotten. Sasirangan seems to be getting out of the hearts of South Borneo people. Therefore, strategic measures are needed to save Sasirangan from extinction. There are at least three things that can be done, namely:

- Transmitting the knowledge of the values contained in Sasirangan. There is a more abandoned Sasirangan by the people of South Borneo because people are less aware of the noble values contained in it. Therefore, the momentum of regional autonomy should be utilized as much as possible to instill local values to the community. One way that can be done is to insert Sasirangan and all its derivatives into local content subjects. By being incorporated into one of the local lessons, there will be a process of transforming the values contained in Sasirangan. Thus, the youth will love it more.

- Having political alignments. There must be a concern from the power holders to make room for Sasirangan to develop itself. For example, providing a training to improve the quality of the craftsmen by the capital assistance and facilitate sales.

- Revitalizing by a process of inheritance through education and the construction of consciousness through political "intervention". Then, another thing to do is to revitalize in: (a) wider use of fabric. Initially, Sasirangan is only used for "talisman" purposes and making fabrics for ceremonial purposes. Later, there is a need to modify it in such a way that the resulting model reflects the modern fashion so that the youths love wearing it. The economical value of a culture is often abandoned by its supporters. It is not because the culture is bad but also because it is unable to promise a better life to its advocates. Therefore, the development of Sasirangan fashion can be accepted by the market needs to continue.

\section{B. The Learning of Character Value on the Use of Additives} Substance in Dying Sasirangan Fabric

The development of learning conditions in the classroom is still not able to link learning with social and cultural contexts of the learners' environment. Banjarese social and cultural contents are rarely raised in the science subjects found at elementary and junior high schools. The subject matter is still abstract, whereas there should be factual, conceptual, and procedural, so that science subjects are considered difficult by students. This is because the delivery of material tends to be boring and less contextual. The material presented refers only to the concept of abstraction and theoretical without connecting with the social and cultural contexts causing the learning less meaningful. Meaningfulness in learning according to Reference [7] is an important thing that can support students learning outcomes that related with the planting of character values. The value of student's characters that can be built as a study of local wisdom education in character education on the use of natural additive substances in dying Sasirangan including:

- The value of confidence. By looking at the history of the existence of Sasirangan, the pattern of the Banjarese belief development is known. The public believes that the cloth was first made by Patih Lambung Mangkurat to fulfill the request of Junjung Buih as a prerequisite to show itself, indicating that Sasirangan has natural identity. Therefore, the people of South Borneo also believe that this cloth has the power to drive out demons. This belief clearly shows that this is a manifestation of the beliefs of the people of South Borneo.

- The cultural value of Sasirangan is one of the cultural achievements of the people of South Borneo. The selection of materials, the way of dying, the colors used, and the making of their patterns is the embodiment of the reading and understanding of the people of South Borneo towards nature and its phenomenon. In addition, the emergence of the pattern combination also shows the creativity of South Borneo people. In other words, Sasirangan is the result of the South Borneo people's society manifested in products of cultural value.

- Economic value. As the times passed, people became increasingly aware of the economic potential contained in such this cloth. This can be seen from the increasing use of Sasirangan from merely evil spirits to various kinds of products, such as party clothes, sandals, bags, and purses. In addition, the increasing value of the local handicrafts provides economic added value. However, it should also be noted that economizing without understanding the spirit contained in Sasirangan can eliminate the "spirit" within it. The use of chemical dyes, for example, may be more effective at making Sasirangan, but it should also be realized that the use of natural chemical dyes could damage the local values contained in Sasirangan.

\section{CONCLUSION}

Sasirangan is used as custom fabrics commonly used in Banjar traditional events. The word Sasirangan is derived from the word "menyirang" which means baste because done in a way to baste then tied with raffia rope and then dyed, until now Sasirangan is still made manually. There are six main colors of Sasirangan made of the natural additive substances contained in the area of South Borneo, namely: (1) yellow from turmeric or temulawak, (2) red from gambier, mengkudu fruit, red lombok, or kesumba, (3) green from pudak leaves or ginger, (4) black from kabuau or uar, (5) purplefrom the seed of gandaria (Banjar Ramania), and (6) brown from uar or rambutan fruit peel. The value of students character can be constructed as a learning on the utilization of natural additive substances on the dying of Banjarmasin Sasirangan cloth such as belief, culture, and economic value. 


\section{REFERENCES}

[1] Maskur, Sejarah Modernisasi Kain Sasirangan, Banjarmasin: Pabrik Irma Sasirangan, 1986.

[2] Prastowo, Pembuatan bahan Ajar INOVATIF, Yogyakarta: Diva Press, 2014.

[3] Anonim, http://www. rubiyah.com, 2008.

[4] BBKB, Pedoman Teknologi Tekstil Kerajinan Tritik, Jumputan dan Sasirangan, Yogyakarta: BBKB, 1989.
[5] H.MJ. Lemmens dan N Wulijarni-Soetjipto, Sumber Daya Nabati Asia Tenggara, No.3 Tumbuhan Penghasil Pewarna dan Tanin, Jakarta: Balai Pustaka, 1999.

[6] S. Susanto, Pengembangan Disain Tekstil Kerajinan dengan ATBM dan Dimensi Hasil Pengembangan, Yogyakarta: Balai Besar Penelitian dan Pengembangan Industri Kerajinan Dan Batik, 2001.

[7] Dimyati \& amp Mudjiono, Belajar dan Pembelajaran. Jakarta: Rineka Cipta, 2002 